\section{Moving About in London}

Pubuic participation in the planning of the future shape of London was the objective of a one-day conference organized by the Greater London Council last Thursday. Londoners have had the chance on other occasions to say what they think about individual planning projects such as the schemes for Barnsbury, Piccadilly, Tower Hamlets, Thamesmead, and more recently Covent Garden; but this was the first large forum for Londoners to discuss their city as a whole ever to be held. Unfortunately, the conference, however well intentioned, could not be described as a great success. The idea of public participation in planning is a splendid one in principle (the new Town and Country Act insists on it), but it is questionable how a gathering of up to 1,000 people or more in a large impersonal hall can yield effective public discussion. The Greater London Council does, however, descrve some tribute for going to the trouble (and expense) of organizing the meeting at all, but the closing impression of many of the participants must have been of a day fizzling along like a damp squib with only two bright sparks of enthusiasm, provided by Peter Hall, professor of geography at Reading University, and by a London taxi-driver. Another disappointment was that the Queen Elizabeth Hall, where the conference was held, was only two-thirds full. This was not the result of public apathy - all of the 500 seats allotted to the general public were filled without difficulty, and some pcople had to be turned away. Many of the specially invited delegates, however, did not trouble to use their tickets; perhaps the cold weather was too much for them. This was a pity, for it was just the sort of conference that should have had the hall bursting at the seams.

Did the conference achievo anything at all ? Probably very little that will influence the GLC planners in their thoughts on the Greater London Development Plan due to go to the Minister of Housing about July next year. The outstanding points to emerge were that people and homes should be put before traffic and developers in planning priorities and that no expense should be spared to site essential roads where they cause as little inconvenience to everyone as possible. Most people in the audience probably agreed with Lord Jellicoe, chairman of the London Amenity and Transport Association, when he called for a com. mission, like that for the third London airport, to study the GLC's motorway plans. This had the support of Mr Duncan Sandys, who also called for no more parking in streets: "tailor our traffic to the roads and not our roads to the traffic". Professor Buchanan spoke of the four main attributes of urban development-safety, convenience, visual interest, and variety.

It was left to Professor Peter Hall to stir the imagination of the audience, far-fetched as some of his schemes may be. He called for monorails above Oxford Street and only pedestrians along it by 1972; the turning of the West End from a "tatty fairground in a rather sordid seaside town" to an Expo every year; office development around the rail terminals of Euston,
King's Cross, London Bridge and Paddington like that planned for Victoria; exciting suburban centres around transport interchanges such as Hendon and Lewisham; and the retention of St Pancras Station as a museum of the railway age. Londoners, he said, should be able to get away from the "noisy areas" into "quiet areas", and it was vital to keep the village communities in London which made the city unique. Unfortunately, London was no longer "as unique as it was when Rasmussen wrote about it", but it was still possible to turn London into the "most livable big city of the world".

The conference might have been more of a success if the public had been better briefed. The planners did mention some of the trends affecting the future development of London-the decline in the population, the reduction in office buildings and of jobs, and so on-. but there is much more that could have been done. And perhaps, in any case, people are more anxious to have answers to simple complaints, such as that of the taxi-driver who complained: "I get locked in traffic eight hours a day. By the ninth, I'm ready for a punch-up".

In another way, Londoners have had a chance recently to voice their protests. For the past fortnight, they have been able to study an excellent exhibition of the GLC's plans for Covent Garden-an area of 93 aeres bounded by Kingsway, High Holborn, Shaftesbury Avenue and the Strand. In 1965, the GLC, the Westminster City Council and the London Borough of Camden agreed to form a consortium to coordinate the redevelopment of the area when the famous fruit and vegetable market moves out in 1972 to Nine Elms in Battersea (see also page 728). Criticisms apart, the scheme is an attempt to revitalize part of central London and to bring moro homes into the area-both good ideas provided the traffic problems are properly managed, and ideas pleaded for in a more general way at the conference on London. One subject everyone at this conference appcared to agree about was the need for better public transport-better bus services and more Underground lines. Events scem at last to be moving in the right direction, to judge from recent developments. The second stage of the new Victoria Line linking Highbury with Warren Street is to open on December 1. The next stage to Oxford Circus and Victoria is planned to open in March next year, and the final extension southwards to Brixton "should be ready in the early 1970s. By then the tunnelling teams will be ready for more work and the London Transport Board is therefore hoping that work on the new Flect Line will be able to go right ahead. If approved, the Fleet line would take over the trains now running from Stanmore and Finchloy Road on the Bakerloo Line. It would then run from Baker Stroet to the Strand by way of Green Park, and then via the Aldwych to a new station at Ludgate Circus. From there it would go to Cannon Street, to a new station at Fenchurch Street and then under the Thames into southeast London. The terminal station has not yet been decided. 